\title{
THE EFFECT OF NATIONAL BREAD, OF IRON MEDICATED BREAD, AND OF IRON COOKING UTENSILS ON THE HAEMOGLOBIN LEVEL OF CHILDREN IN WAR-TIME DAY NURSERIES
}

\author{
BY \\ HELEN M. M. MACKAY, M.D., F.R.C.P., \\ Member of the Staff of the Medical Research Council, \\ R. H. DOBBS, M.D., M.R.C.P., Major R.A.M.C., \\ Physicians to the Queen Elizabeth Hospital for Children, London, \\ AND \\ KAITILIN BINGHAM, \\ Assistant, Pathological Department, Royal Free Hospital
}

The presence in war-time day nurseries of groups of young children provided an opportunity for investigating anaemia in children under five years of age. There are, however, considerable drawbacks to such investigations in day nurseries. Chief among these are the high rate of cross-infections, the unstable population, and the investigator's ignorance, from lack of contact with the mothers, of the children's life outside the nursery.

\section{Aims of the investigation}

The investigation was concerned with the etiology of anaemia as seen in the nurseries. The initial object was to determine whether or not a small addition of iron to the children's bread, made from 85 per cent. extraction flour, would produce a rise in haemoglobin level. If this fortification proved effective, it might be a valuable means of ensuring a sufficient supply of iron to the general population, and might provide evidence regarding the normal mean haemoglobin level in children of pre-school age. White bread 'fortified' with iron (4 to $16 \mathrm{mgm}$. $\mathrm{Fe}$ in each pound) and other substances is in wide use in the United States (Tobey, 1942; Editorial, $J$. Amer. med. Ass., 1945), but no evidence appears to exist as to the influence on health of iron medication in this form. Observations were also made on the influence of national bread, without medication, and of iron cooking utensils on the haemoglobin level. The haemoglobin level of the children in the nurseries was compared with mean values obtained about a year earlier of children attending welfare centres. Changes in haemoglobin level in the nurseries and the effect of diet and of drug therapy will be dealt with in another article.

Technique of haemoglobin estimation

The blood was taken from a prick in the heel with a cutting needle after the foot had been warmed in hot water. Though the foot was always warmed it proved impossible always to ensure a warm leg, and this or resistance and crying on the part of a child probably produced fallacious values in individual cases. Three different observers made the estimations, but all estimations at any one nursery were made by the same observer. All estimations were made with a Haldane colour tube, and the same colour tube and set of diluting tubes were used at all the nurseries. Figures given have had the National Physical Laboratory correction factor applied for colour tube and pipettes, and a mean percentage correction factor for the diluting tubes. This percentage correction was necessary because the distance between the 20 and 140 marks, and hence the diameter of the diluting tubes, differed from the B.S.I. standard. The National Physical Laboratory provided further small corrections for these diluting tubes which were obviously negligible and were omitted. At 80 per cent. the mean of the corrections omitted was -0.3 and the maximum individual correction ignored was $-0 \cdot 9$.

\section{Clinical material}

The children were aged six months to five years, and attended one or other of three day nurseries in Islington, in north London. The nurseries, which we will call A, B and C could accommodate 55, 66 and 33 children respectively, or 154 in all. They were open from 7 a.m. to 7 p.m. on six days weekly. The mothers, in addition to their home duties, were engaged on work outside their own homes, and, with few exceptions, this outside work was full time. They included factory hands, railway porters, bus conductors, with some shop assistants, canteen workers and nursery workers. A few were engaged in clerical work. Breakfast, dinner and tea were supplied in the nurseries, but some children, varying from about a quarter to half the total number, had breakfast at home and no breakfast at the nursery. Probably all children had a meal at home at night 
after their 3.30 p.m. nursery tea, and most had some food before arrival. As the mothers kept the children's ration books, it was possible for them to give rationed food at home: to what extent this was done is unknown. At each of the three nurseries $\mathrm{A}, \mathrm{B}$ and $\mathrm{C}$, the children were divided into two groups, as nearly as possible equal as regards haemoglobin level, age, sex and incidence of infected tonsils or bronchitis at the time of starting treatment, and one group received medicated bread and the other acted as a control. No iron medication other than that provided in the ironfortified bread was given in these nurseries. The number of children finally available for comparison in this part of the investigation was 138 , out of a total of 197 examined during August, 1942, to February, 1943.

\section{Haemoglobin level by age at beginning of observation compared with the haemoglobin level of a group of children attending welfare centres}

The mean initial haemoglobin level of the nursery children aged one to two years averaged somewhat lower than that of those aged six to twelve months (table 1). Thereafter there was a fairly steady increase in haemoglobin level with each year of life up to five years of age, when the children left to attend school. These trends were fairly consistent at each of the three nurseries and the rise with age was much steeper than in the groups of children of school age examined by us. The mean figure for all three nurseries at one to two years old was 73.2 per cent. and at four to five years 85.5 per cent., a rise of 12 per cent. in three years, or an average rise of 4 per cent. per year, in contrast with about 1.4 per cent. yearly rise which we found in school children between the ages of seven and eleven years (Dobbs et al., 1944). Though the mean haemoglobin values at nursery $\mathbf{B}$ were slightly lower than at the other two nurseries, this may well have been due in the main to a difference in colour matching. The estimations at nursery $A$ were made by H.M.M.M. and those at nursery B by K.B. K.B., in a series of ten test colour matchings (conducted by Dr. R. G. Macfarlane for the Haemoglobin Survey Committee of the Medical Research Council), gave readings averaging approximately 2 per cent. lower than H.M.M.M.'s matchings on the same series. This difference in colour matching, if consistent, would almost balance the mean difference in readings at nurseries $\mathbf{A}$ and $\mathbf{B}$. R.H.D. made the estimations at nursery $C$ until the end of the present investigation in February, 1943, but he did not take part in this colourmatching test as he was by then in the army. Table 1 includes, for the sake of comparison, haemoglobin values (corrected as already indicated in this paper) for children of similar age examined at welfare centres in 1941 (Wills, Mackay, Bingham and Dobbs, 1942). These had at each age over twelve months a higher mean haemoglobin level than any of the present three nursery groups at the outset of the investigation. The differences varied at different ages between about 3.5 and 5.5 per cent. above the mean for the two nurseries examined by the same two observers who made the estimations on nearly all the welfare children. Since these differences are consistent, and appear in every small subdivision, it may fairly be assumed to be a real difference and not due to chance, in spite of the fact that the difference in haemoglobin level between each age group at nurseries $\mathrm{A}$ and $\mathrm{C}$, as compared with the corresponding group at the welfare centres, is sometimes more and sometimes less than twice its standard error.

Other nursery children examined in 1941, like those in the present series, had a mean haemoglobin level lower than this welfare group.

TABLE 1

HAEMOGLOBIN LEVEL BY AGE AT BEGINNING OF OBSERVATION IN AUGUST AND SEPTEMBER, 1942

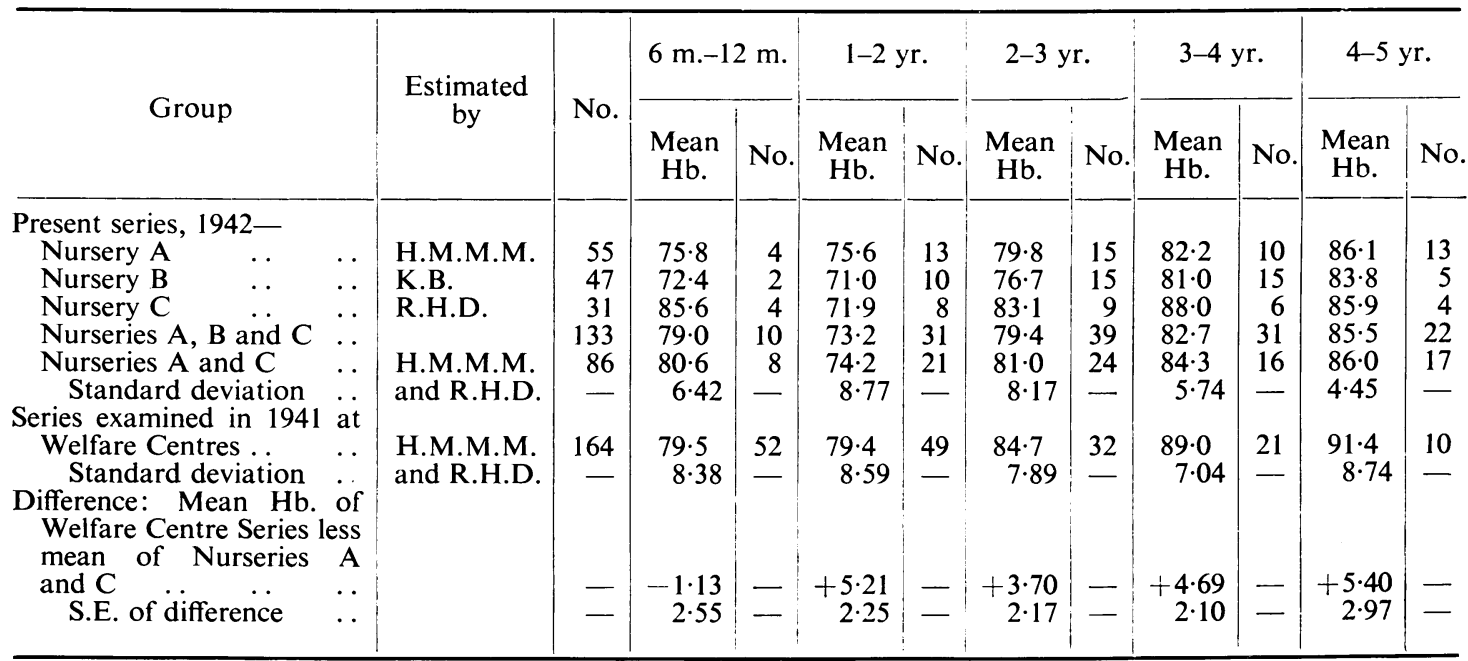




\section{Medicated bread}

At each nursery one group received National bread made of 85 per cent. extraction flour, the other group received the same National bread with an addition of ferrous carbonate to provide an additional $7 \mathrm{mgm}$. of $\mathrm{Fe}$ in each ounce of bread. The ferrous carbonate was incorporated in the common salt habitually added in making the bread. We are indebted to Dr. R. A. McCance and Miss E. M. Widdowson for help and advice about this 'fortification' of the loaf, as it is called in the United States. The writers mistakenly assumed that by the summer of 1942 all flour used in bakeries had an addition of calcium carbonate, and it was impossible at the end of the period of observation to find out which batches had been so treated, as the flour was derived from many sources. By Christmas 1942 , i.e. approximately half-way through the investigation, about half the bread in the country, according to information available, was being fortified with calcium, and the proportion of bread so fortified steadily increased.

The addition of ferrous carbonate to the bread made it look slightly darker than unmedicated bread, but since the difference was slight, direct comparison was necessary to be sure of the colour difference. The taste was scarcely affected, and the two breads could not be distinguished by taste with any certainty even on direct comparison. The addition of ferrous sulphate, in the same quantity, gave the bread a slightly greenish-grey appearance, hence this salt was considered unsuitable for the purpose of the investigation.

Quantity of bread consumed and the increase in iron intake provided by medication of the bread. Bread, in some form, was usually provided at breakfast and tea in the nurseries. The average daily intake was estimated by weighing, at each meal for one week, all the bread consumed by the children over one year old at two nurseries. All children received National bread, and ate during the week an average of 2 to 3 ounces daily per head for all ages between one and five years, whether or not the bread contained the added ferrous carbonate. The estimate was a rough one and the intake varied widely on different days of the week, depending in part on what other cereal foods were provided. On different days of the week the average consumption per head in the group aged one to two years varied between $\frac{3}{4}$ and $4 \frac{3}{4}$ ounces and in the group aged three-and-a-half to five years it varied between 2 and $5 \frac{1}{2}$ ounces. Hence, on different days of the week, the amount of iron derived from the addition of ferrous carbonate to the bread varied from about 5 to $33 \mathrm{mgm}$. of Fe per head for children aged one to two-and-a-half years, and from 14 to $38 \mathrm{mgm}$. per head for those aged three-and-a-half to five years. Children of all ages between one and five years having breakfast and tea in the nursery received an average addition of $20 \mathrm{mgm}$. of Fe per head per day; those having tea only received about 14 mgm. daily. Thus far more iron was provided than could possibly have been derived from unmedicated food alone. In the particular week when the estimate of bread intake was made the smaller children at nursery $\mathrm{A}$ ate a good deal more bread than the corresponding age group at nursery $\mathbf{B}$.

Effect of medicated bread. The observation with medicated bread continued for five months until February, 1943, and haemoglobin estimations were repeated at intervals of four to six weeks during this period. At each nursery the children receiving the medicated bread and their controls had similar haemoglobin levels throughout the five months (tables 2 and 3). The small differences in mean haemoglobin level between the medicated children and the controls are obviously due to the small numbers in each group. The medicated bread had, therefore, no influence on the haemoglobin level. The percentage of days missed by children having medicated bread and by controls was also almost identical, namely 25 per cent. (calculated to the nearest whole number) of total possible attendances. This figure applies to the absences at the two largest nurseries combined (see table 5).

\section{Effect of National bread}

The National bread was made from 85 per cent. extraction flour; from March, 1942, the law required that not less than 75 per cent. of the flour in bread must be of 85 per cent. extraction. The consumption of National bread was without any effect on the

TABLE 2

HAEMOGLOBIN LEVEL OF CHILDREN RECEIVING IRON MEDICATED BREAD AND NATIONAL BREAD-ALL AVAILABLE CHILDREN

\begin{tabular}{|c|c|c|c|c|c|c|c|c|c|c|c|}
\hline & & \multicolumn{2}{|c|}{$\begin{array}{l}1942 \\
\text { Aug. and Sept. }\end{array}$} & \multicolumn{2}{|c|}{ Oct. } & \multicolumn{2}{|c|}{ Nov. } & \multicolumn{2}{|c|}{$\begin{array}{l}1943 \\
\text { Jan. }\end{array}$} & \multicolumn{2}{|c|}{ Feb. } \\
\hline & & $\begin{array}{c}\text { Mean } \\
\text { Hb. }\end{array}$ & No. & $\begin{array}{l}\text { Mean } \\
\text { Hb. }\end{array}$ & No. & $\begin{array}{c}\text { Mean } \\
\text { Hb. }\end{array}$ & No. & $\begin{array}{c}\text { Mean } \\
\text { Hb. }\end{array}$ & No. & $\begin{array}{c}\text { Mean } \\
\mathrm{Hb} .\end{array}$ & No. \\
\hline $\begin{array}{l}\text { Nursery A. } \\
\text { Nursery B. } \\
\text { Nursery C. }\end{array}$ & $\begin{array}{l}\text { Medicated bread } \\
\text { National bread } \\
\text { Medicated bread } \\
\text { National bread } \\
\text { Medicated bread } \\
\text { National bread }\end{array}$ & $\begin{array}{l}80 \cdot 2 \\
80 \cdot 8 \\
78 \cdot 7 \\
76 \cdot 2 \\
81 \cdot 5 \\
82 \cdot 2\end{array}$ & $\begin{array}{l}30 \\
25 \\
24 \\
23 \\
16 \\
15\end{array}$ & $\begin{array}{l}81 \cdot 9 \\
84 \cdot 0 \\
78 \cdot 9 \\
78 \cdot 5 \\
83 \cdot 3 \\
81 \cdot 5\end{array}$ & $\begin{array}{l}27 \\
27 \\
25 \\
27 \\
15 \\
13\end{array}$ & $\begin{array}{l}86 \cdot 8 \\
86 \cdot 2 \\
80 \cdot 8 \\
78 \cdot 4 \\
77 \cdot 7 \\
77 \cdot 9\end{array}$ & $\begin{array}{r}27 \\
25 \\
17 \\
20 \\
9 \\
11\end{array}$ & $\begin{array}{l}86 \cdot 2 \\
87 \cdot 7 \\
- \\
\overline{79 \cdot 9} \\
80 \cdot 8\end{array}$ & $\begin{array}{l}18 \\
15 \\
- \\
9 \\
6\end{array}$ & $\begin{array}{l}89 \cdot 6 \\
88 \cdot 5 \\
77 \cdot 8 \\
77 \cdot 9 \\
81 \cdot 9 \\
79 \cdot 7\end{array}$ & $\begin{array}{r}23 \\
16 \\
20 \\
18 \\
11 \\
9\end{array}$ \\
\hline
\end{tabular}


haemoglobin level at nurseries $B$ and $C$ where the mean haemoglobin of children having the National bread, whether medicated or not, remained almost unchanged for five months. The mean haemoglobin level of children at nursery $A$ rose by about $8 \frac{1}{2}$ per cent. in five months, but, as the National bread was without effect on the haemoglobin level in the other two nurseries, it is difficult to suppose that the rise can be attributed to the bread.

TABLE 3

HAEMOGLOBIN LEVEL OF CHILDREN RECEIVING IRON MEDICATED BREAD AND NATIONAL BREAD-CHILDREN WHO WERE EXAMINED IN AUGUST OR SEPTEMBER, 1942, AND RE-EXAMINED IN JANUARY OR FEBRUARY, 1943

\begin{tabular}{|c|c|c|c|c|c|}
\hline & \multicolumn{2}{|c|}{$\begin{array}{l}1942 \text { Aug. } \\
\text { or Sept. }\end{array}$} & \multicolumn{2}{|c|}{$\begin{array}{l}1943 \text { Jan. } \\
\text { or Feb. }\end{array}$} & \multirow{2}{*}{$\begin{array}{l}\text { Differ- } \\
\text { ence } \\
\text { between } \\
\text { first and } \\
\text { last } \\
\text { estimate }\end{array}$} \\
\hline & $\begin{array}{c}\text { Mean } \\
\text { Hb. }\end{array}$ & No. & $\begin{array}{c}\text { Mean } \\
\mathrm{Hb} .\end{array}$ & No. & \\
\hline \multicolumn{6}{|l|}{ Nursery A- } \\
\hline Medicated bread. . & $80 \cdot 0$ & 26 & $89 \cdot 3$ & 24 & $+8 \cdot 9$ \\
\hline \multicolumn{6}{|l|}{ Nursery B- } \\
\hline Medicated bread. . & $80 \cdot 6$ & 17 & $78 \cdot 9$ & 17 & $-1 \cdot 7$ \\
\hline National bread .. & $77 \cdot 3$ & 15 & $78 \cdot 8$ & 15 & $+1 \cdot 5$ \\
\hline \multicolumn{6}{|l|}{ Nursery C- } \\
\hline Medicated bread.. & 83.9 & 12 & $80 \cdot 3$ & 12 & $-3 \cdot 6$ \\
\hline National bread ... & $79 \cdot 7$ & 11 & $80 \cdot 0$ & 11 & $+0 \cdot 3$ \\
\hline
\end{tabular}

\section{Morbidity rate and haemoglobin level}

The steady rise in haemoglobin at nursery $\mathbf{A}$ in the autumn and winter of 1942-43 (tables 2 and 4) was present in each age group and in almost every child in the group. The rise could not have been due to any muddle whereby controls received the medicated bread, since the results in the other nurseries over the same period showed that the medicated bread was without effect on the haemoglobin level.

A difference in morbidity rate as a possible explanation of this difference in haemoglobin level needed investigation. A record was kept by the matron and sister at each nursery of the absences of each child, with, if known, the cause of absence.
TABLE 4

HAEMOGLOBIN LEVEL OF CHILDREN AT NURSERY A COMPARED WITH THAT AT NURSERIES B AND C-CHILDREN ON MEDICATED BREAD AND ON NATIONAL BREAD COMBINED

\begin{tabular}{|c|c|c|c|c|c|c|c|c|}
\hline & \multicolumn{3}{|c|}{$\begin{array}{l}\text { 1942, Aug. } \\
\text { and Sept. }\end{array}$} & \multicolumn{3}{|c|}{ 1943, Feb. } & \multicolumn{2}{|c|}{$\begin{array}{c}\text { Final } \\
\text { mean less } \\
\text { initial } \\
\text { mean }\end{array}$} \\
\hline & $\begin{array}{c}\text { Mean } \\
\text { Hb. }\end{array}$ & S.D. & $\begin{array}{c}\text { No. } \\
\text { of } \\
\text { chil- } \\
\text { dren }\end{array}$ & $\begin{array}{c}\text { Mean } \\
\mathrm{Hb} .\end{array}$ & S.D. & $\begin{array}{c}\text { No. } \\
\text { of } \\
\text { chil- } \\
\text { dren }\end{array}$ & Diff. & $\begin{array}{l}\text { S.E. } \\
\text { of } \\
\text { diff. }\end{array}$ \\
\hline $\begin{array}{l}\text { Nursery A } \\
\text { Nursery B } \\
\text { Nursery C }\end{array}$ & $\begin{array}{l}80 \cdot 4 \\
77 \cdot 4 \\
81 \cdot 8\end{array}$ & \begin{tabular}{|l|}
$7 \cdot 90$ \\
$7 \cdot 32$ \\
$8 \cdot 81$
\end{tabular} & $\begin{array}{l}55 \\
47 \\
31\end{array}$ & $\begin{array}{l}89 \cdot 2 \\
77 \cdot 9 \\
80 \cdot 9\end{array}$ & \begin{tabular}{|l|}
$5 \cdot 59$ \\
$6 \cdot 94$ \\
$7 \cdot 26$
\end{tabular} & $\begin{array}{l}39 \\
38 \\
20\end{array}$ & $\begin{array}{r}+8.8 \\
+0.5 \\
-0.9\end{array}$ & $\begin{array}{l}1 \cdot 39 \\
1 \cdot 55 \\
2 \cdot 27\end{array}$ \\
\hline
\end{tabular}

The great majority of absences were due to illness of the child, but children were also kept away on account of quarantine for contact with an infectious illness, illness of the mother, or return on leave of a father in the Forces. The rules for exclusion on account of contact with infection were identical at all the nurseries. Hence the absence rate is not strictly an index of the morbidity rate of the children but, in view of possible differences in recording at different nurseries, it seemed the best index available. Therefore periods of absence, irrespective of cause, were compared. Many children ceased attendance altogether after developing an illness. As approximately the same proportion of children in each nursery left because of illness, a child ceasing attendance for good after, for example, developing measles, ceased to be reckoned as a member of his group from the day of his last attendance, though, of course, this involved an underestimate of the child's total period of illness. The incidence of infections, particularly respiratory tract infections, was high, often nearly every child in the nursery had a running nose, and one cold followed close on the heels of another. Children were not excluded for colds in the head.

Table 5 shows the percentage of days missed by the children at the two larger nurseries and their

TABLE 5

PERCENTAGE OF DAYS ABSENT AND HAEMOGLOBIN LEVELS AT NURSERY A AND NURSERY B

\begin{tabular}{|c|c|c|c|c|c|c|c|c|c|c|c|c|c|c|}
\hline \multirow{4}{*}{ Nursery } & \multirow{4}{*}{$\begin{array}{l}\text { Aug. } \\
\text { and } \\
\text { Sept. } \\
1942 \\
\text { Mean } \\
\text { Hb. }\end{array}$} & \multicolumn{3}{|c|}{$\begin{array}{c}\text { Sept. 21-Nov. 15, } \\
1942\end{array}$} & \multirow{4}{*}{$\begin{array}{l}\text { Nov. } \\
1942 \\
\text { Mean } \\
\text { Hb. }\end{array}$} & \multicolumn{3}{|c|}{$\begin{array}{l}\text { Nov. 15, 1942- } \\
\text { March 5, } 1943\end{array}$} & \multirow{4}{*}{$\begin{array}{l}\text { Feb. } \\
1943 \\
\text { Mean } \\
\text { Hb. }\end{array}$} & \multicolumn{3}{|c|}{$\begin{array}{l}\text { Sept. 21, 1942- } \\
\text { March 5, } 1943\end{array}$} & \multirow{2}{*}{\multicolumn{2}{|c|}{$\begin{array}{c}\text { Sept. 21, 1942-March 5, } \\
1943 \\
\text { Days absent as per cent. } \\
\text { of total possible attend- } \\
\text { ance }\end{array}$}} \\
\hline & & \multirow{2}{*}{$\begin{array}{c}\text { Pos- } \\
\text { sible } \\
\text { attend- } \\
\text { ance }\end{array}$} & \multicolumn{2}{|c|}{ Absences } & & \multirow{3}{*}{$\begin{array}{c}\text { Pos- } \\
\text { sible } \\
\text { attend- } \\
\text { ance }\end{array}$} & \multicolumn{2}{|c|}{ Absences } & & \multirow{3}{*}{$\begin{array}{c}\text { Pos- } \\
\text { sible } \\
\text { attend- } \\
\text { ance }\end{array}$} & \multicolumn{2}{|c|}{ Absences } & & \\
\hline & & & \multirow[t]{2}{*}{ Days } & \multirow{2}{*}{$\begin{array}{l}\text { Per } \\
\text { cent. }\end{array}$} & & & \multirow{2}{*}{ Days } & \multirow{2}{*}{$\begin{array}{l}\text { Per } \\
\text { cent. }\end{array}$} & & & \multirow{2}{*}{ Days } & \multirow{2}{*}{$\begin{array}{l}\text { Per } \\
\text { cent. }\end{array}$} & \multirow{2}{*}{$\begin{array}{c}\text { Children on } \\
\text { National } \\
\text { bread }\end{array}$} & \multirow{2}{*}{$\begin{array}{l}\text { Children on } \\
\text { Medicated } \\
\text { bread }\end{array}$} \\
\hline & & Days & & & & & & & & & & & & \\
\hline A & $80 \cdot 4$ & 3208 & 504 & $15 \cdot 7$ & $86 \cdot 6$ & 5346 & 1412 & $26 \cdot 4$ & $89 \cdot 2$ & 8554 & 1916 & $22 \cdot 4$ & & \\
\hline B & $77 \cdot 4$ & 3268 & 551 & $16 \cdot 9$ & $79 \cdot 5$ & 5819 & 1969 & $33 \cdot 8$ & $77 \cdot 9$ & 9087 & 2520 & $27 \cdot 7$ & & \\
\hline
\end{tabular}


haemoglobin levels. Between September, 1942 and March, 1943, i.e. during the whole period of this observation, the children at nursery $\mathbf{B}$, where the haemoglobin level was stationary, were absent for 28 per cent. of their possible total attendance; those at nursery $\mathrm{A}$, where the haemoglobin level rose, for 22 per cent. However, the main rise in haemoglobin level at nursery A occurred before the middle of November and the main difference in the absence rates occurred after the middle of November; from September to the middle of November the absence rates were roughly similar, the percentage of days missed at nursery $A$ being 15.7 and nursery $C$ 16.9. By November the mean haemoglobin level at nursery A was already about $7 \frac{1}{2}$ per cent. higher than at nursery $\mathbf{B}$ in spite of the very small difference in the morbidity rates up to that date. Thus the difference in morbidity rate followed the improved haemoglobin level at nursery A. The lower morbidity rate at nursery A may have resulted from the higher haemoglobin level but did not cause it. It is, of course, arguable that the types of infection at the two nurseries differed in their effect on haemoglobin level, but there is no evidence that infections were of a more severe type at nursery $\mathrm{B}$ during the period in question.

\section{Iron cooking utensils and iron intake}

It has been suggested that iron cooking utensils may have provided an important source of dietary iron for our ancestors in past centuries. The present investigation offered an opportunity for examining the effect of iron cooking vessels on the iron intake of these small children. At nursery A, where the children showed a rise in haemoglobin level in the autumn and winter of 1942-43, more cooking was done in iron utensils than at the other two nurseries, and some of the enamelled saucepans were considerably chipped, exposing the iron base. Hence possible gross 'contamination' or 'fortification' of the food from this source was next investigated. Thanks are due to Dr. R. A. McCance and Miss E. M. Widdowson for their generous help and the large amount of time they gave to estimating the degree of iron contamination due to the various cooking vessels used. Table 6 shows that apple cooked in an aluminium saucepan contained $0.19 \mathrm{mgm}$. of iron per $100 \mathrm{gm}$.; cooked in the polished iron saucepan used for fruit at nursery $\mathrm{A}$, the iron content was increased fifteenfold; cooked in an old-fashioned heavy black iron saucepan at nursery B it was increased fivefold. During the latter part of 1942 , while the investigation was in progress, apples were frequently provided at the nurseries, but at nursery $B$ they were given raw 'when possible', whereas at nursery $\mathbf{A}$ cooked apple was regularly given. Potato, not being acid, showed little iron contamination during cooking. At nursery A a stock pot was in daily and constant use and the stock received prolonged cooking each day, first in a polished iron saucepan, from which it was transferred to a chipped enamel one for further cooking. At nursery $B$ the stock was cooked in an aluminium pot and the particular sample examined contained only about onenineteenth of the quantity of iron found in the sample from nursery A. It is not, however, known what were the original ingredients or the initial iron content of either sample of stock.

\section{TABLE 6}

EFFECT OF IRON COOKING UTENSILS ON IRON CONTENT OF FOOD (MISS E. M. WIDDOWSON)

\begin{tabular}{|c|c|c|c|}
\hline $\begin{array}{l}\text { Food- } \\
\text { stuff }\end{array}$ & Nursery & Cooking utensil & $\begin{array}{c}\text { Fe mgm. } \\
\text { per } \\
100 \mathrm{gm} .\end{array}$ \\
\hline Apple & $\begin{array}{l}\text { Nursery A } \\
\text { Nursery B }\end{array}$ & $\begin{array}{l}\text { Aluminium } \\
\text { Polished iron * } \\
\text { Chipped enamel } \\
\text { Iron, blackened * }\end{array}$ & $\begin{array}{l}0 \cdot 19 \\
2 \cdot 88^{*} \\
0 \cdot 52 \\
0 \cdot 99^{*}\end{array}$ \\
\hline Potato & $\begin{array}{l}\text { Nursery A } \\
\text { Nursery B }\end{array}$ & $\begin{array}{l}\text { Aluminium } \\
\text { Chipped enamel } * \\
\text { Aluminium * } \\
\text { Polished iron }\end{array}$ & $\begin{array}{l}0.40 \\
0.52 * \\
0.58^{*} \\
0.46\end{array}$ \\
\hline Stock & $\begin{array}{l}\text { Nursery A } \\
\text { Nursery B }\end{array}$ & $\begin{array}{l}\text { Polished iron } \\
\text { Polished iron } \rightarrow \text { chipped } \\
\text { enamel } * \\
\text { Aluminium * }\end{array}$ & $\begin{array}{l}1 \cdot 77 \\
2 \cdot 67^{* \dagger} \\
0 \cdot 14^{* \dagger}\end{array}$ \\
\hline
\end{tabular}

* Usual cooking utensil for foodstuff concerned at this nursery.

$\dagger$ Original ingredients of stock not the same.

It seemed, therefore, that iron cooking utensils might account for the rising haemoglobin level at nursery A, and, if so, this would be a really important finding. However, further investigation did not bear this out.

A comparison was made of the iron content (exclusive of the iron that derived from medication of the bread) of one week's food intake of children between two and three-and-a-half years old at nursery $A$ and at nursery $B$ respectively. Unfortunately the iron intake was estimated when the medicated bread investigation was over and the figures in table 7 cannot be taken as indicating the

TABLE 7

IRON CONTENT OF DIET IN MILLIGRAMMES

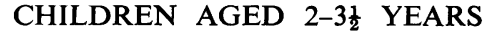

\begin{tabular}{|c|c|c|c|c|c|}
\hline \multirow[b]{2}{*}{$\begin{array}{l}\text { Date } \\
1943\end{array}$} & \multicolumn{2}{|c|}{ Nursery A } & \multicolumn{2}{|c|}{ Nursery B } & \multirow{2}{*}{ Comments } \\
\hline & $\begin{array}{l}\mathrm{Fe} \\
\text { in } 6 \\
\text { days }\end{array}$ & $\begin{array}{l}\mathrm{Fe} \\
\text { per } \\
\text { day }\end{array}$ & $\begin{array}{l}\mathrm{Fe} \\
\text { in } 6 \\
\text { days }\end{array}$ & $\begin{array}{l}\mathrm{Fe} \\
\text { per } \\
\text { day }\end{array}$ & \\
\hline $\begin{array}{l}\text { May } 24 \\
\text { May } 30\end{array}$ & $23 \cdot 2$ & 3.9 & - & - & $\begin{array}{l}\text { Diet included } \\
\text { scarcely any } \\
\text { fruit. }\end{array}$ \\
\hline May $31 .$. & - & - & - & - & $\begin{array}{l}\text { Diet improved at } \\
\text { all nurseries. }\end{array}$ \\
\hline $\begin{array}{l}\text { June 2- } \\
\text { June } 9\end{array}$ & - & - & $34 \cdot 6$ & $5 \cdot 8$ & $\begin{array}{l}\text { Diet included } \\
\text { scarcely any fruit }\end{array}$ \\
\hline $\begin{array}{l}\text { Aug. 28- } \\
\text { Sept. } 3\end{array}$ & $24 \cdot 4$ & $4 \cdot 1$ & - & - & $\begin{array}{l}\text { A little cooked fruit } \\
\text { given daily. }\end{array}$ \\
\hline $\begin{array}{l}\text { Sept. 4- } \\
\text { Sept. } 10\end{array}$ & 一 & - & $26 \cdot 7$ & $4 \cdot 4$ & $\begin{array}{l}\text { A little cooked fruit } \\
\text { given daily. }\end{array}$ \\
\hline
\end{tabular}


relative iron intake at the two nurseries between August, 1942, and February, 1943, when the investigation was in progress. Unknown to the authors, considerable changes and improvements in all the nursery diets were instituted from May 31, 1943, onwards. At nursery A the first week's collection of food was before the improvement of the diet and at nursery $B$ the first collection of food was just after the change in feeding, so that unfortunately no comparison is possible of the iron intake from natural sources during the period covered by the haemoglobin estimations set out in tables 2 and 3. Since acid foods are most likely to take up iron on cooking, it would be in the fruit season that augmentation of the iron intake from cooking vessels made of this metal would be most marked. Hence if a difference in cooking utensils caused the rising haemoglobin level at nursery $A$, then in the fruit season the iron content of the diet at that nursery should be materially higher than that at nursery B. In May or June, 1943, and again in the fruit season in August and September, 1943, samples of food as nearly as possible the same as the actual intake of an individual child were collected by one of us at each meal daily for a week and the samples pooled. A different child was chosen at random at each meal. When the child was on medicated bread, plain National bread was substituted in the sample. During the test weeks in August and September, 1943, cooked fruit was given daily; the fruit helpings, however, were small, e.g. one small plum or an equivalent bulk of apple. The result of the analysis was disappointing. In both weeks the iron intake was greater at nursery $\mathrm{B}$ where there was less cooking in iron vessels. The conclusion follows that there cannot have been any gross iron contamination of the food at nursery A from cooking utensils, and the use of iron cooking utensils at the nursery would not influence the haemoglobin level. This seems a legitimate conclusion in spite of the fact that the iron content of the diet at nursery B during the autumn and winter of 1942-43 was probably distinctly lower than it was at the dates of the iron analyses, by which time the diet had been improved. Since neither morbidity rate nor the type of cooking utensils in use provided an explanation of the difference in haemoglobin level at nurseries $A$ and $B$ by the end of 1942 , it is probable that it was the result of a better diet at nursery $\mathrm{A}$, but the data available as to the diets at this period are very incomplete.

\section{Discussion}

The beneficial effect of any line of treatment can only be shown on a group of persons who are subnormal and hence it is necessary to know whether or not these nursery children were anaemic at the outset of the investigation. The normal mean haemoglobin level for children of six to twelve months is not less than 86 per cent. (Mackay, 1933), but the normal mean level in children after the age of infancy is not known, still less the range of the normal. There is no doubt, however, that the mean initial haemoglobin level in these nursery children was subnormal. This is shown (1) by the fact that the mean initial haemoglobin values of the nursery children at each year of age were consistently lower than those of children examined at welfare centres in 1941 (moreover there is reason to suppose that this welfare group itself included many children with subnormal haemoglobin levels), and (2) by the rise in mean haemoglobin level at all the nurseries during 1942-44, which it is hoped to discuss in another paper.

It has been suggested that consumption of National bread with a considerably higher iron content than white bread has had a beneficial effect on haemoglobin levels in this country (Davidson et al., 1944a and b). At nurseries B and C, the haemoglobin level, though subnormal, remained stationary in spite of the consumption of 2 to 3 ounces daily of National bread. This result is in accordance with the metabolic observations published by Widdowson and McCance (1942) showing the poor absorption by the human subject of iron from bread made of flour of high extraction.

The type of anaemia common in this country in babies and young children, particularly those aged six months to three years, has been shown by many workers to respond to iron therapy (Mackay and Goodfellow, 1931; Parsons and Hawksley, 1933; Davidson and Fullerton, 1938), and is commonly accepted as an iron deficiency anaemia, though the deficiency of iron may be conditioned by other factors. As there seemed no reason to suppose the anaemia at the nurseries was of a different type, a therapeutic effect from the iron medicated bread was expected. The expected rise in haemoglobin did not occur. This fact might be due to any one of several causes, e.g. (1) that the anaemia was not an iron deficiency anaemia, (2) that the high incidence of intercurrent illness prevented response to iron, (3) that the dose was inadequate, (4) that the iron was precipitated by the phytic acid in the bread and consequently not absorbed.

The effect of a liberal dose of iron in the form of a mixture has been tested in the nurseries, and a rise in haemoglobin, albeit a small one, was obtained. (These results await further analysis.)

Various factors, known and unknown, influence the degree of absorption of iron and its utilization in haemoglobin building. One of these is certainly infection (Mackay and Goodfellow, 1931; Parsons and Hawksley, 1933) and the morbidity rate at the nurseries was high. Fullerton (1937) found in the children of a residential nursery, as a result of infections in the late winter and spring months, actually a considerable drop in haemoglobin level in spite of iron medication, but when health improved in the summer haemoglobin rose with iron treatment. There is thus every reason to suppose that in these nurseries too illness would retard a rise in haemoglobin level. But it seems improbable that illness was sufficient at nursery $B$ in the autumn of 1942 to prevent a rise in haemoglobin level which would otherwise have occurred from the con- 
sumption of iron medicated bread, since a similar amount of illness did not prevent a rise in haemoglobin level in nearly every child at nursery A over this period.

As regards the size of the daily dose of iron received by the children in the medicated bread, this, though variable, was a large intake as measured by dietetic standards and a very small intake by therapeutic standards: a mean intake per head of 14 and $20 \mathrm{mgm}$. respectively for children not having and for children having breakfast at the nursery. Why the effective therapeutic dose of iron is so grossly in excess of any quantity obtainable in the food is as yet unexplained, but even allowing for the large size of the ordinary therapeutic dose, one would have expected in five months some response in case of iron deficiency anaemia from the quantity of iron given had there been no hindrance to its utilization.

There remains the possibility that 85 per cent. extraction flour is a quite unsuitable vehicle for iron medication, that iron phytate was formed and absorption was consequently very poor. Widdowson and McCance (1942) have demonstrated in the human subject the greatly reduced iron absorption from bread made from 92 per cent. extraction flour as compared with white flour on account of the insolubility of iron phytate. It is supposed that there was enough phytic acid present in 85 per cent. extraction flour to combine with much of the iron added to the bread. One of us (Mackay, 1940) has given infants soya flour (Berczeller process) in quantities to supply about $10 \mathrm{mgm}$. of iron daily for a $12 \mathrm{lb}$. baby. Most soya flour contains a considerable amount of phytic acid (McCance, personal communication). This soya feeding diminished the incidence of anaemia in infants, but did not prevent severe nutritional anaemia in a few cases, anaemia which was cured by giving full doses of iron as a drug. These findings are compatible with the view that phytic acid diminished, but did not inhibit, the utilization of the iron present. As it has not been possible to compare the relative proportion of phytic acid and of iron in the medicated bread and the soya flour used, nor the possible influence of other bases present, the reason why the iron in the soya flour was apparently better utilized than that in the bread cannot be suggested. It is of interest that Nakamura and Mitchell (1943) found that iron phytate and the iron in whole wheat was only about half as well utilized in haemoglobin building by the young rat as was the iron of ferrum redactum or sodium iron pyrophosphate, both of which are used in the fortification of white flour in the United States.

There is left the fact that fortification of the National loaf with iron, with a consequent increase of the iron content of the diet by about 14 to $20 \mathrm{mgm}$. daily, did not produce a rise in mean haemoglobin level among children with a subnormal haemoglobin level, and that the most likely cause seemed to be the presence in the bread of phytic acid. It is hoped further investigation will show whether com- parable quantities of iron given in a mixture will increase the haemoglobin level.

It is an interesting fact that iron cooking utensils had little influence on the iron intake at nursery $A$. Though the iron saucepans in use greatly increased the iron content of stewed fruit, the quantity of cooked fruit consumed at these nurseries was so small that its influence on the total iron intake was negligible. Incidentally it is unlikely that iron cooking utensils influenced our ancestors' haemoglobin level unless they consumed large quantities of cooked fruit.

\section{Summary and conclusions}

Observations were made at three war-time day nurseries with accommodation for one hundred and fifty-four children ranging in age from six months to five years. Haemoglobin estimations were made with a Haldane haemoglobinometer at intervals of four to six weeks. The sickness rate was high and the average attendance of the children was about three out of four possible attendances over the five month period of the investigation. The mean haemoglobin level was subnormal at the outset: in infants aged six to twelve months it was about 79.0 per cent., and in infants of one to two years 73.5 per cent., with thereafter a progressive rise to 85.5 per cent. by four to five years. The mean value was lower than that of children examined at welfare centres the year before. At each nursery half the children received for five months National bread, made from 85 per cent. extraction flour, and the other half the same bread fortified with $7 \mathrm{mgm}$. iron (reckoned as Fe) per ounce, which provided the children with far more iron than they could have obtained from natural sources. The average daily intake of bread by children aged one to five years was about 2 to 3 ounces, providing about 14 to $20 \mathrm{mgm}$. of additional iron. This medicated bread was without effect on the haemoglobin level or the morbidity rate. It is suggested that the phytic acid of 85 per cent. extraction flour interfered with the utilization of the added iron. National bread made from 85 per cent. extraction flour was itself without effect on the haemoglobin level over a period of five months.

Iron cooking utensils were in use at one nursery but did not make an appreciable difference to the mean iron intake of the children as the consumption of cooked fruit was small.

Though the high incidence of infections was probably a factor influencing the haemoglobin level, it did not prevent a rise of about 8 per cent. in the mean haemoglobin level of children at nursery $A$ between September, 1942 and February, 1943. The absentee rate during the material period was similar at nursery $\mathbf{A}$ and nursery $\mathbf{B}$, and the rising haemoglobin level at nursery $A$ was probably due to a better diet, but adequate data to establish this inference are lacking. This investigation supports the view that 85 per cent. extraction flour is not a good vehicle for increasing iron consumption. 


\section{Acknowledgements}

The authors' sincere thanks are due to Dr. V. Freeman, Medical Officer of Health of Islington, as well as to all those who undertook much extra work in difficult times to make our investigation possible, especially to Dr. K. H. Hirst, Deputy and Acting Medical Officer of Health, to the Matrons and Staffs at the nurseries, to the pharmacists at the Queen Elizabeth Hospital for Children, to Mrs. P. Dagnall for technical assistance and to Messrs. Beales \& Co., who supplied us with medicated bread. Thanks are also due to Dr. R. A. McCance and Miss E. M. Widdowson for valuable advice and for all the food analyses on which the conclusions are based.

\section{REFERENCES}

Davidson, L. S. P., and Donaldson, G. M. M. (1944a). Brit. med. J., 1, 76. —, Lindsay, S. T., and Roscoe, M. H. (1944b). Ibid., 2, 333 .
Davidson, L. S. P., and Fullerton, H. W. (1938). Edinb. med. J., N.S. (4th), 45, 193.

Dobbs, R. H., Mackay, H. M. M., and Bingham, K. (1944). Brit. med. J., 2, 748.

Editorial (1945). J. Amer. med. Ass., 127, 160.

Fullerton, W. H. (1937). Arch. Dis. Childh., 12, 91.

King, E. J., Gilchrist, M., and Matheson, A. (1944). Brit. med. J., 1, 250.

Macfarlane, R. G., and O'Brien, J. R. P., et al. (1944). Loc. cit., 248.

Mackay, H. M. M. (1933). Arch. Dis. Childh., 8, 221. (1940). Ibid., 15, 1.

- , and Goodfellow, L. (1931). Spec. Rep. Ser. Med. Res. Council, Lond., no. 157, p. 31.

Nakamura, F. L., and Mitchell, H. H. (1943). J. Nutrit., $25,39$.

Parsons, L. G., and Hawksley, J. C. (1933). Arch. Dis. Childh., 8, 117.

Tobey, J. A. (1942). Arch. Pediat., 59, 653.

Widdowson, E. M., and McCance, R. A. (1942). Lancet, $1,588$.

Wills, L., Mackay, H. M. M., Bingham, K., and Dobbs, R. H. (1942). J. Hyg., Camb., 42, 505. 